\title{
Criminologie in 2040
}

\author{
Tom Vander Beken
}

Het werken met scenario's laat toe om op een dynamische manier aan toekomstverkenning te doen. Rond de onzekerheden interdisciplinariteit en de relatie van het criminologisch onderzoek ten aanzien van de wereld buiten de wetenschap worden vier scenario's voor de criminologie in 2040 uitgetekend. Crime Science en Strafbeleid beschrijven de situatie waarin een sterk opgenomen publieke rol respectievelijk aan een hoge en lage graad van interdisciplinariteit wordt gekoppeld. Da Vinci en Theoretische criminologie schetsen een toekomst met beperkte publieke rol voor de criminologie met respectievelijk veel en weinig ruimte voor interdisciplinariteit.

\section{Inleiding}

Verjaardagen zijn uitgelezen momenten om iets of iemand in de bloemetjes te zetten en te feliciteren. Vaak is het een moment voor een terugblik en gemijmer over het verleden. Maar altijd is er ook een wens voor de toekomst bij: nog vele jaren!

Ook tijdschriften criminologie verjaren en verdienen een feestje waarin wensen worden uitgesproken. Ik ben dan ook blij met de uitnodiging voor het diamanten jubileum van het Tijdschrift voor Criminologie en complimenteer de kranige zestiger met het mooie en relevante traject. Ik wens het een fijne toekomst toe. Hoe die toekomst er zou kunnen uitzien, hangt in belangrijke mate af van wat de perspectieven zijn voor de criminologie als onderzoeksveld. Dat laatste maakt het voorwerp uit van deze bijdrage.

Het uitdenken en neerschrijven van toekomstontwikkelingen wordt door velen als een prettige, maar toch vooral vrijblijvende oefening gezien. Wat daarbij gezegd en geschreven wordt, geeft in het beste geval aanleiding tot verdere discussie of een glimlach, maar wordt in de regel niet echt serieus genomen. Uitspraken over de toekomst en voorspellingen lijken eerder iets voor waarzeggers op de kermis dan voor wetenschappers. Laat staan voor criminologen. Ten onrechte.

Bijna vijftien jaar geleden begon ik mijn bijdrage voor het jubileumnummer van een zustertijdschrift uit Vlaanderen als volgt:

'Voor mij ligt het jubileumnummer van de 50ste jaargang van Panopticon van januari 2029. Voor de gelegenheid wordt het tijdschrift, dat al meer dan tien jaar niet meer in afzonderlijke nummers verschijnt, nog eens in zijn oude vorm en exclusief in het Nederlands uitgegeven. Een bundeltje gedrukt papier met een editoriaal, een aantal stukken over de geschiedenis van het blad en nieuwsbrieven van de verschillende deelredacties met een overzicht van hun 
werkzaamheden. De stukken over Panopticon zijn zoals vroeger van voetnoten voorzien in plaats van de gebruikelijke hypertext. Het nummer bevat niets anders dan gedrukte tekst en kan niet zonder meer gekoppeld worden aan een andere informatiedrager. Behoudens de letters is er geen beeld, klank of ander signaal dat wordt uitgezonden. Het nummer wordt de abonnees persoonlijk bezorgd. De nieuwsbrieven van de deelredacties veiligheid, welzijn, bedrijf, natuur, cultuur, technologie en criminologie die voor één keer nog onder het kopje "Rubrieken" worden samengebracht, rapporteren over heel diverse zaken: afgerond preventieonderzoek in opdracht van de Europese Defensie, een voorstel tot afschaffing van de gevangenisstraf, statistische gegevens over werknemerssancties in de banksector, een congres over watercriminaliteit rond de Ganges, een stukje over E. Ferri naar aanleiding van zijn overlijden honderd jaar geleden (...).' (Vander Beken, 2005, 1)

Hoewel die intro uiteraard eerder als gimmick was bedoeld, blijft het interessant om het toekomstbeeld van toen naast de situatie van vandaag te leggen. Mijn prognose over de vorm van het tijdschrift was, althans voor Panopticon, fout. Het tijdschrift verschijnt nog steeds netjes op papier en in het Nederlands. De accuraatheid van de voorspelling over inhoudelijke aspecten van het tijdschrift zal pas binnen tien jaar kunnen worden afgetoetst. Iets over halfweg lijkt wat ik toen schreef iets beter overeind te blijven. We zullen zien. Meer valt met een dergelijke vorm van toekomstverkenning evenwel niet te doen. Iemand schetst een beeld van wat volgens hem of haar komen zal en nadien wordt gekeken of (en in welke mate) dit zich heeft gerealiseerd.

Dit is een niet zo relevante en sterk verouderde visie op toekomstverkenningen en wat daarmee kan worden gedaan. In eerder onderzoek (Vander Beken \& Verfaillie, 2010) heb ik geargumenteerd dat het maken en inzetten op één toekomstbeeld weinig zinvol is. Het voorspellen van wat dé toekomst zal zijn, is gebaseerd op een zeer statische en deterministische visie op (maatschappelijke) ontwikkelingen. De idee dat de toekomst nu al vastligt, miskent het belang van onzekerheden en sluit in essentie elk handelingsgericht denken uit. Wat baat het om (anders) te handelen als de toekomst toch niet veranderd kan worden?

Het werken en denken met scenario's laat toe om op meer dynamische manier aan toekomstverkenning te doen, waarbij onzekerheden wel een plaats kunnen krijgen. Ik ben een overtuigd voorstander en gebruiker van een scenariomethode en maakte daarvan uitgewerkte (Vander Beken, 2006; Vander Beken \& Verfaillie, 2010) en eerder korte (Vander Beken, 2009; Vander Beken \& Pauwels, 2013; Vander Beken \& Herkes, 2017) toepassingen.

In deze bijdrage doe ik voor de ontwikkeling van de criminologie als onderzoeksveld iets gelijkaardigs. $\mathrm{Na}$ een korte toelichting over de scenariotechniek, presenteer ik vier scenario's over de criminologie in 2040. Het kan dan meteen ook een aanzet zijn voor een terugblik in een bijdrage in het eiken jubileumjaar van het tijdschrift. 


\section{Scenario's maken: wat als?}

Scenario's laten toe om naast en soms zelfs los van elkaar verschillende toekomstbeelden te ontwikkelen waarin onzekerheden een belangrijke rol spelen. Scenariodenken is eeuwenoud en vooral vanuit de militaire strategie bekend. Wie niet absoluut zeker is dat de vijand over het land, door de lucht of via de zee zal komen, doet er goed aan niet enkel na te denken over de optie die op basis van de beschikbare informatie de meest waarschijnlijke is en zich enkel daarop voor te bereiden. Veel zinvoller is het om voor elk van de plausibele mogelijkheden na te gaan wat er dan zou kunnen gebeuren. Blijkt dat één van die scenario's bijzondere uitdagingen stelt of voorbereiding vraagt, dan kan het zin hebben daarop te anticiperen en bij te sturen. Dat is zeker het geval indien blijkt dat in elk van de uitgedachte scenario's situaties kunnen ontstaan waarop de troepen onvoldoende voorbereid zijn.

Scenario's zijn dan ook geen voorspellingen, maar instrumenten om na te denken over toekomstbeelden en dat te koppelen aan eventueel anticipatief handelen.

Scenario's kunnen op verschillende manieren ontwikkeld en gebruikt worden samen met andere methoden. Wanneer het thema van de scenario-oefening duidelijk is, wordt in een eerste beweging op zoek gegaan naar externe factoren die het onderwerp van het scenario zouden kunnen beïnvloeden (voor een meer gedetailleerde beschrijving van de techniek, zie Vander Beken \& Verfaillie, 2010). Het is de bedoeling dat de zoektocht naar deze factoren (driving forces) een lijst oplevert van elementen uit de omgeving waarvan aangenomen wordt dat zij van invloed kunnen zijn op de evolutie van het onderwerp van het scenario. In het geval van de scenario's voor de legeraanvoerder die een aanval verwacht, kunnen deze elementen bijv. betrekking hebben op de getalsterkte van de tegenstrever of de te verwachten logistieke ondersteuning ervan (aantal vliegtuigen of boten).

Bij meer algemene en complexe scenario's - bijv. deze over bepaalde gevolgen van deviant gedrag - zullen bredere sociale, politieke, economische en technologische ontwikkelingen vaak in het lijstje opduiken. Het opstellen van die lijst is een intellectuele gedachteoefening die de betrokkenen dwingt na te denken over de eigen inzichten en keuzes. Voor een scenario-oefening is het van belang om externe factoren te selecteren die relevant en belangrijk zijn voor het thema, maar wel 'onzeker'. In het licht van wat hoger werd gezegd, dient het adjectief 'onzeker' met alle omzichtigheid te worden gehanteerd. Geen enkele evolutie kan immers als 'zeker' worden aangemerkt. Een 'onzekere' externe factor in deze scenariocontext dient dan ook begrepen te worden als een factor of evolutie waarvan rond beide polen ervan een zinvol en relevant verhaal kan worden opgebouwd. Voor de legeraanvoerder die 'onzeker' is over het feit hoeveel vliegtuigen de tegenstrever heeft om eventueel een luchtaanval te wagen, kan de hoeveelheid vliegtuigen een relevante 'onzekere' factor zijn. Hij is dan ook gebaat met een scenario waarin zowel een toekomst geschetst wordt waarin de tegenstrever weinig vliegtuigen heeft, als een waarin hij er zeer veel heeft.

In een volgende fase is het nuttig om enkele (bijv. twee) relevante 'onzekerheden' te distilleren en elke pool ervan te combineren en te integreren, zodat zij telkens aanleiding kunnen geven tot meerdere (bijv. vier) scenario's. Deze scenario's kunnen dan dienen als reflectiekader om na te gaan wat die verschillende toekomst- 
beelden betekenen en wat eventueel kan gebeuren om bepaalde scenario's te voorkomen of net te bewerkstelligen. Scenario's dienen dan ook voldoende plausibel en geloofwaardig te zijn en onderbouwd om als overtuigende spiegel te kunnen fungeren. Zij worden in de tegenwoordige tijd geschreven om een zo plausibel mogelijke voorstelling te maken van een 'wat als?'-situatie. Waarschijnlijkheid is uitdrukkelijk geen kwaliteitscriterium voor scenario's. Ook de meest onwaarschijnlijke verhalen kunnen zeer relevante inzichten aanreiken over uitdagingen. Hoewel het onmogelijk is om in het kader van deze zeer beperkte bijdrage een volwaardige scenariostudie te maken over de ontwikkeling van het criminologisch onderzoek - scenario's kunnen niet 'zomaar' worden geschreven, zij zijn het resultaat van grondig en methodologisch onderbouwd onderzoek rond 'zekerheden' en 'onzekerheden' -, wordt hierna toch een aanzet daartoe gegeven.

\section{Onzekerheden over de ontwikkeling van het criminologisch onderzoeksveld}

De scenario-oefening over de ontwikkeling van het criminologisch onderzoeksveld wordt opgebouwd rond de volgende twee onzekerheden: interdisciplinariteit en de publieke rol van de criminologie (voor een zeer korte oefening in die zin, zie Vander Beken, 2019).

Een eerste onzekerheid heeft te maken met de ontwikkeling van disciplines binnen het wetenschappelijk onderzoek. Aan de ene kant is een evolutie denkbaar waarbij disciplines, waaronder de criminologie, zich verder maar los van elkaar blijven ontwikkelen. In een dergelijk elan zou de criminologie, zoals sommigen dit eerder voorspelden (Zahn, 1999), wel eens een van de meest succesvolle disciplines van de 21e eeuw kunnen worden. Dit zou inhouden dat de criminologie, naast andere wetenschapsdisciplines, verder in omvang en in wetenschappelijke kracht zou toenemen. En een eigen profiel heeft als discipline met eigen gerenommeerde onderzoekers en tijdschriften. Wetenschappers uit andere onderzoeksdomeinen kunnen in de criminologie te gast zijn, maar worden er niet als volwaardige criminologen beschouwd. Het gevolg daarvan is dat er zeer beperkte interactie en uitwisseling is met wat in andere disciplines gebeurt die een gelijkaardige op zichzelf gerichte evolutie doormaken. Onderzoek en onderzoekers uit verschillende disciplines passeren elkaar als schepen in de nacht (Loader \& Sparks, 2010, 20). Die relatie tot andere disciplines is dan ook niet de allereerste bekommernis van de criminologie. Veel belangrijker is het om binnen de criminologie zelf de cohesie te bewaren en overzicht te houden. De verdere professionalisering en specialisatie van de criminologie leidt immers intern tot het ontstaan van verschillende subdisciplines en scholen, die elkaar soms eerder bekampen dan lezen (Bruinsma, 2016).

Aan de andere kant is het mogelijk dat disciplines in de wetenschappen veel minder belang en impact krijgen en dat wetenschappelijk onderzoek eerder rond vragen en thema's wordt geclusterd. Bij een dergelijke ontwikkeling beschikt de criminologie veel minder over een eigen domein en worden criminologen, naar Thorsten Sellin, 'koningen zonder koninkrijk'. Vragen die gerelateerd zijn aan criminaliteit of onveiligheid zijn niet exclusief voor criminologen. Sociologen, 
psychologen, geografen, statistici, medici of economisten kunnen deze vragen ook (mee)beantwoorden. In de organisatie van het onderzoek leidt dit tot een afkalving van de grenzen tussen onderzoeksdomeinen, met veel aandacht voor interdisciplinariteit. Ontwikkelingen in het Europees wetenschapsbeleid en wetenschapsfinanciering wijzen in een dergelijke richting. Bij de ontwikkeling van het nieuwe kaderprogramma Horizon Europe 2021-2027 van de Europese Unie was er discussie of inclusive and secure societies in een dan wel twee onderzoeksclusters moest worden gevat. Indien beide afzonderlijk zouden worden opgenomen (en gefinancierd), zouden er meer mogelijkheden en duidelijk afgebakende mogelijkheden komen voor sociale wetenschappers om zich (op het inclusieve gedeelte) te profileren. Indien alles in één cluster zou worden ondergebracht, moeten sociale wetenschappers hoe dan ook veel meer samen met STEM-wetenschappers (science, technology, engineering, mathematics) aan de slag in interdisciplinaire consortia. In dergelijke samenwerkingsverbanden zal iedereen evenwel naar een eigen plaats moeten zoeken op basis van relevantie voor de te behandelen vragen. Dit kan ertoe leiden dat criminologie als aparte wetenschapsdiscipline sterk aan belang inboet, verschrompelt, of zelfs verdwijnt.

Een tweede onzekerheid betreft de relatie van het criminologisch onderzoek ten aanzien van de wereld buiten de wetenschap. Hoe zal criminologie zich verhouden tot het beleid? Welke maatschappelijke impact zal de criminologie binnen twintig jaar hebben? Het zijn vragen waarop het antwoord onzeker is, maar belangrijk is om na te denken over wat criminologie in de toekomst zou kunnen zijn. Loader en Sparks $(2010,10)$ omschreven criminologie eerder als een successful failure om een deel van de onzekerheid en ambiguiteit rond de ontwikkelingen in de discipline weer te geven. Aan de ene kant zien we dat de criminologie floreert. Er zijn meer en meer criminologen die steeds beter en met meer kennis van zaken hun vak uitoefenen. Aan de andere kant lijkt deze ontwikkeling helemaal niet gevolgd te worden door een groeiende maatschappelijke en beleidsmatige visibiliteit en impact van de criminologie. Hoewel er op dat vlak zeker verschillen zijn tussen regio's en landen - Nederland heeft op dat vlak bijvoorbeeld een heel ander profiel dan Frankrijk -, blijft de publieke rol die criminologie krijgt of neemt een belangrijke onzekere factor, waarvan beide polen een exploratie verdienen. Aan het ene uiterste wordt de criminologie vooral een wetenschap en profileert ze zich als dusdanig. Ze trekt zich terug in een eigen discours en communiceert weinig wat buiten de muren van haar ivoren toren gebeurt. In vele gevallen is de criminologie best kritisch ten aanzien van beleid en maatschappelijke ontwikkelingen, zonder zich evenwel te bekommeren om een eventuele vertaling van deze kritiek in dialoog of actie op het publieke forum. Aan het andere uiterste zien we een criminologie die er helemaal voor kiest om de vragen die er op een bepaald moment maatschappelijk en beleidsmatig toe doen, tot de hare te maken. De criminologie levert dan vooral kennis en technieken vanuit haar discipline, maar gaat volledig op in een maatschappelijke rol. Loader en Sparks (2010, 28-38) hebben tussen die twee uitersten vijf types van criminologisch engagement uitgedacht: 
1 de scientific expert die zich toelegt op het verwerven van kennis over criminaliteit en die allerhande interventieprogramma's test op hun bijdrage aan de terugdringing van criminaliteit en onveiligheid;

2 de policy advisor die het als zijn of haar opdracht beschouwt om de politieke klasse te informeren en te adviseren over vraagstukken die betrekking hebben op misdaad en straf;

3 de observed-turned player die besluit om zijn of haar handen vuil te maken omdat hij of zij meent dat criminologisch onderzoek de politieke agenda enkel kan beïnvloeden door middel van directe deelname aan het beleidsproces;

4 de social movement theorist/activist die zich richt op het ontwikkelen van een kritisch en alternatief discours - en dit vaak ten dienste van de meest gemarginaliseerden; en ten slotte

5 de lonely prophet (de eenzame profeet die deelneemt aan de grote debatten).

De typologie die Loader en Sparks $(2010,115)$ uiteindelijk zelf prefereren van de democratic under-labourer, die op een bescheiden en integere manier wil bijdragen tot een beter strafrechtelijk beleid, bevindt zich ergens in het midden van onze twee uitersten. Voor de scenario-oefening die we hier maken, is die normatieve oefening over de 'beste' rol van de criminoloog niet aan de orde. Wij gaan ervan uit dat het onzeker is of we naar een criminologie van scientific experts dan wel van lonely prophets evolueren, en dat beide kanten van het spectrum een exploratie verdienen.

\section{Scenario's voor criminologie in 2040}

\section{Onzekerheden combineren}

De twee onzekerheden en hun respectievelijke polen vormen het kader voor vier toekomstscenario's. Ik heb de scenario's telkens een naam gegeven die een hoogleraar in een dergelijke ontwikkeling zou kunnen dragen: Crime Science beschrijft de situatie waarin een grote interdisciplinariteit wordt gekoppeld aan een uitgesproken publieke rol. Strafbeleid schetst een wereld met een lage graad van interdisciplinariteit en een sterk opgenomen publieke rol. Da Vinci geeft een toekomst met een hoge graad van interdisciplinariteit en een beperkte publieke rol. Theoretische criminologie is een scenario waarin een beperkte interdisciplinariteit aan een beperkt opgenomen publieke rol wordt gekoppeld.

\section{Crime Science}

In oktober 2040 geeft de nieuwe hoogleraar Crime Science in haar oratie toelichting bij wat zij de komende jaren aan onderzoek beoogt te doen. Als nieuwe houder van een leerstoel aan het Ministerie van Veiligheid legt ze uit dat ze een traditie wil verder zetten waarin ze wetenschappelijke methoden wil inzetten om vraagstukken van veiligheid en samenleven aan te pakken (Laycock, 2005). Ze is bio-ingenieur van opleiding en heeft voor haar proefschrift een nieuwe toepassing ontwikkeld voor de DNA-databank van de politie. Ze geeft aan dat de inzichten en 
methoden uit de natuurwetenschappen haar zullen leiden in haar onderzoek naar veiligheid en samenleven en legt uit dat ze op die manier hoopt verdere doorbraken in de criminaliteitspreventie te kunnen bewerken. Op het einde van haar oratie reageert ze ook subtiel op de kritiek die haar aanstelling destijds heeft teweeggebracht. Ze weet zeer goed dat ze van haar voorgangers verschilt, omdat ze geen opleiding criminologie, sociologie, psychologie of andere sociale wetenschappen heeft en tot nog toe nooit in een tijdschrift heeft gepubliceerd dat expliciet criminologie tot voorwerp heeft. Ze geeft aan dat dit ook net de sterkte kan zijn van haar onderzoek en onderzoeksprogramma doordat zij, zonder te moeten stilstaan bij allerhande complexe mechanismen over mensen en systemen, met zeer betrouwbare instrumenten en methoden op zoek kan gaan naar wat werkt voor het departement Veiligheid en Samenleving.

\section{Strafbeleid}

De bekendmaking van de naam van de nieuwe hoogleraar strafbeleid die in het najaar van 2040 een voltijdse aanstelling aan de Universiteit Amsterdam zal opnemen, is nieuws voor de voorpagina van de kwaliteitskranten. Amper een dag nadat zij haar ontslag als eerste minister had aangeboden, kondigt de flamboyante veertiger haar overstap aan naar de universiteit. In een uitgebreid interview op de middenpagina van de krant geeft de premier toelichting bij die carrièreswitch. Hoewel ze als studente al politiek actief was, is ze na haar master criminologie en veiligheidsbeleid nog een aantal jaren aan de universiteit gebleven. Ze heeft in die periode ook haar proefschrift afgewerkt rond het gebruik van voedingssupplementen in de gevangenissen. Daarna is ze enkele jaren als gevangenisdirecteur aan de slag geweest en heeft ze op het ministerie in Den Haag anderhalf jaar de onderzoekseenheid 'hersenen en beleid' geleid. Daarna is ze voltijds politiek actief geworden en als een komeet in het politieke landschap naar boven geschoten. Ze geeft aan dat het nu tijd is, ook al is dit voor velen onverwacht, om naar de universiteit terug te keren. Ze is ervan overtuigd dat ze nu meer dan wie ook kennis heeft van waar het in de criminologie en veiligheid om gaat. Als hoogleraar strafbeleid is ze van plan haar politieke ervaring en kennis mee te valoriseren, en dit in constante dialoog met de beleidsverantwoordelijken. In haar onderzoeksprogramma staat onderzoek naar interventies gericht op gedragsmodificatie bij gedetineerden centraal.

\section{Da Vinci}

De Leidse Da Vinci-leerstoel gaat in 2040 naar een hoogleraar uit de Verenigde Staten. De universiteit Leiden is erg trots dat ze de leider van het onderzoekslab Human Science voor die positie heeft kunnen strikken. De Nederlandse roots en familiale situatie van de hoogleraar hebben zeker mee de doorslag gegeven om naar Nederland te komen en de positie op te nemen. De hoogleraar is wetenschapsfilosoof en wiskundige en is doctor multiplex in zowel wiskunde als crime science en politieke wetenschappen. Sinds kort is ook bekend dat ze de auteur is van een onder een pseudoniem gepubliceerd kinderboek, dat vorig jaar met de Gouden Griffel werd bekroond. In haar oratie legt de nieuwe hoogleraar uit hoe zij human science ook in Nederland verder wil ontwikkelen. Zij zet zeer sterk in op 
haar onderzoekslijn inzake energie, waarin zij grote aandacht heeft voor data en theorieën met betrekking tot normen en normoverschrijdingen. Om die reden heeft zij in dat onderdeel van haar lab naast fysici, chemici, biologen, sociologen, filosofen en juristen nu ook iemand aangetrokken die een criminologieopleiding heeft genoten. Toen ze op de receptie na haar oratie werd gefeliciteerd door de Minister van Energie en Klimaat en de Minister van Samenleving, had ze geen idee wie ze de hand schudde.

\section{Theoretische criminologie}

De nieuwe hoogleraar theoretische criminologie heeft flink van zich afgebeten in het kerstnummer van het studentenblad in 2040. Hij vindt de beslissing om het onderzoeksgeld voor het departement criminologie verder terug te schroeven ongehoord en meent daarin vooral een maneuver te zien om het kritische en fundamenteel onderzoek van de groep te fnuiken. Hij geeft aan dat zijn onderzoeksgroep nochtans tot de wereldtop van de discipline behoort. Zopas is iemand van zijn groep er opnieuw in geslaagd om een publicatie in het tijdschrift met de hoogste impactfactor in de criminologie geplaatst te krijgen. Maar zijn groep blijft te klein om het ambitieuze onderzoeksprogramma rond etiologie uit te voeren. Dit is des te meer het geval nu het Ministerie van Veiligheid enkel nog de eigen onderzoeksprojecten financiert en geen ruimte meer heeft voor niet specifiek geoormerkt onderzoek. De hoogleraar verwijst in zijn interview naar de lovende woorden die het panel van de onderzoeksvisitatie recent voor het wetenschappelijk werk van zijn groep overhad. De aanbeveling dat hij die mooie onderzoeksresultaten misschien ook verder kon valoriseren en daarover communiceren, heeft hij opgenomen. Volgende maand verschijnt zijn eerste nieuwsbrief.

\section{Besluit}

De scenario-oefening voor de criminologie in 2040 bleef binnen het bestek van deze bijdrage zeer beperkt en niet echt uitgewerkt. Dat was ook niet de bedoeling. Het was een manier om kort een verjaardagswens uit te spreken en het tijdschrift een mooie toekomst toe te wensen. En aan te geven dat de toekomst van de criminologie nog vele kanten op kan en dus nog helemaal niet vast hoeft te liggen. Er valt nog zoveel te gebeuren en te beslissen dat het weinig zinvol zou zijn slechts één bepaalde toekomst voor te spiegelen. De gepresenteerde scenario's tonen verschillende plausibele werelden binnen de dimensies interdisciplinariteit en publieke rol van criminaliteit. Dit liet toe heel verschillende soorten hoogleraren van de toekomst te portretteren. Weliswaar met de grove borstel. Maar misschien herkennen we wel het silhouet van onszelf of van wie we (niet) willen zijn. Misschien is wel nog een vijfde scenario denkbaar, waarin de vier scenario's kunnen worden geïntegreerd. Allemaal nog verder te boetseren. 


\section{Literatuur}

Bruinsma, G. (2016). Proliferation of crime causation theories in an era of fragmentation. Reflections on the current state of criminological theory. European Journal of Criminology, 13(6), 659-676.

Laycock, G. (2005). Defining crime science. In: M.J. Smith \& N. Tilley (eds.). New approaches to preventing and detecting crime. Devon: Willan, 3-24.

Loader, I. \& Sparks, R. (2010). Public criminology? New York: Routledge.

Vander Beken, T. (2005). Denken over toekomst en scenario's in de criminologie. Panopticon, 26(5), 1-9.

Vander Beken, T. (ed.). (2006). European organised crime scenarios for 2015. Antwerpen/ Apeldoorn: Maklu.

Vander Beken, T. (2009). Vrijheidsberoving en strafbeleid: scenario's voor de toekomst. In: T. Daems, P. Pletincx, L. Robert, V. Scheirs, A. van de Wiel \& K. Verpoest (eds.). Achter tralies in België. Gent: Academia Press, 75-90.

Vander Beken, T. (2019). Future of European criminology. Newsletter of the European Society of Criminology, 18(2), 2-4.

Vander Beken, T. \& Herkes, G. (2017). Scenario's voor de gevangenis van de toekomst. Justitie 2020. Straffen: Waarom? Hoe?/Justice 2020. Punir: Pourquoi? Comment? Antwerpen/Apeldoorn: Maklu, 183-221.

Vander Beken, T. \& Pauwels, L. (2013). Wat als er honderd jaar criminologie aan de Universiteit Gent was? In: M. Cools, T. Daems, A. De Boeck, T. Decorte, B. De Ruyver, L. Pauwels, N. Persak, P. Ponsaers \& C. Vandeviver (eds.). 75 jaar criminologie aan de Universiteit Gent. Antwerpen: Maklu, 99-117.

Vander Beken, T. \& Verfaillie, K. (2010). Assessing European futures in an age of reflexive security. Policing and Society: An International Journal of Research and Policy, 20(2), 187-203.

Zahn, M. (1999). Thoughts on the future of criminology. Criminology, 37(1), 1-16. 